\title{
South Korea's Saemaul (New Village) movement: an organisational technology for the production of developmentalist subjects
}

\author{
Jung Won Sonn* and Dong-Wan Gimm \\ University College London, London, United Kingdom
}

\begin{abstract}
This paper uses the Foucauldian concepts of governmentality and apparatus (dispositive) to understand how the state can use an organisational technology to penetrate everyday life through hegemonic discourse. With a case study of the Saemaul (New Village) movement, a rural development initiative in South Korea in the 1970s, we analyse how the state used half-civilian, half-bureaucratic agents called Saemaul leaders to inscribe the discourse of developmentalism in the peasants' bodies and souls. This article claims that organisational technology plays a critical role in the diffusion of hegemonic discourse during rapid structural transformations such as the industrialisation of South Korea.
\end{abstract}

\begin{abstract}
RÉSUMÉ Ce travail s'appuie sur les notions foucaldiennes de « gouvernementalité » et de « dispositif » pour analyser la façon dont l'Etat emploie les technologies d'organisation pour pénétrer la vie quotidienne des citoyens à travers les discours hégémoniques favorisant le développement. Les auteurs utilisent comme cas d'étude le mouvement Saemaul (mouvement du nouveau village), une initiative créée par le gouvernement sud-coréen pour encourager le développement rural dans les années 1970. Les auteurs analysent, en particulier, le rôle des agents, à la fois civils et politiques, dans la transmission du discours au sein de l'esprit et du corps des paysans. Les auteurs constatent que les technologies d'organisation étudiées dans l'article jouent un rôle essentiel dans la diffusion des discours hégémoniques soutenant le développement et l'industrialisation.
\end{abstract}

Keywords:developmental state; rural development; South Korea; Saemaul; Foucault

\section{Introduction}

The literature on late industrialisation in East Asia typically focuses on the economic and political rationalities of the policies used by the nation state. However, the literature tends to overlook the fact that the compatibility between economic policies and the people affected by those policies is also important to the success of those policies. To address this gap in the literature, this article examines how the government attempted to change citizens' conduct in their everyday work and life situations so that their conduct would become more compatible with policies geared toward industrialisation. More specifically, we examine how the state extended itself to increase its influence over its citizens by creating a half-civilian and half-bureaucratic organisation.

The focus of our study is the Saemaul movement, also known as the New Village movement, which was created in rural South Korea during the 1970s. In particular, we examine the role of the state-appointed Saemaul leaders in the Saemaul movement. We chose this case because it allowed

\footnotetext{
* Corresponding author. Email: j.sonn@ucl.ac.uk
} 
us to effectively observe the way the state intervenes in and changes the conduct of its people. This case is of particular interest because a large "cultural lag" developed in South Korea during a period of rapid industrialisation in the 1970s (Ogburn 1922). Ogburn described cultural lag as the difference in the rate of change between different aspects of a culture. In this case, a cultural lag occurred between the rapid material changes and the slow rate at which people's conduct changed. ${ }^{1}$ In South Korea, where industrialisation occurred extremely rapidly, the cultural lag was likely to have been quite large. Moreover, this lag was more clearly visible in rural areas owing to disparities in development between cities and rural villages. In the 1960s, South Korean cities experienced rapid industrialisation. In rural villages, however, peasants continued to maintain traditional social relations and conduct. To address this cultural lag, the state created the Saemaul movement, which has arguably been its largest and most aggressive intervention into rural society.

The empirical research in this study uses rich and detailed textual data drawn from two sources. The first source, Local Administration, is a monthly publication produced by the Korea Local Administration Mutual Aid Association. In the 96 issues published between 1971 and 1978, we found 93 speeches and memoirs written by Saemaul leaders. The second source, Glorious Footsteps, is a publication produced by the Division of Saemaul movement, Ministry of Home Affairs. In Volumes 2, 3 and 4 (published in 1979, 1980 and 1982, respectively), we found 64 memoirs written by Saemaul leaders. The resulting 157 texts were qualitatively analysed. These memoirs and speeches contain the leaders' descriptions of themselves and their own work. In addition, these texts were presented in venues organised by the authoritarian government. Therefore, to avoid potential bias, we cross-checked the data with findings presented in academic articles written by social scientists in Korean.

\section{Beyond the hegemony of the developmental state}

South Korea is one of several rare economies that moved beyond its status as a "developing" country within only a few decades. In the field of development studies, as well as in cognate disciplines, it is relatively well established that state intervention played a pivotal role in this rapid change in status (Chang 1994). Unlike the majority of authoritarian regimes that operated in the developing world following World War II, Park Jung Hee's government committed itself to economic development in order to compensate for the regime's lack of political legitimacy as well as to compete with the then-successful North Korean socialist economy (Woo 1991). The state developed long-term plans, which were implemented through administrative guidance, industrial policy, financial regulation and protectionist trade policy (Chang 1994). During this process, Park Jung Hee protected the bureaucracy from outside interest groups so that it could implement policies that benefited the national economy without being influenced by interest groups (Evans 1995). Consequently, the Park Jung Hee regime is often referred to as a developmental state; it is often compared to the states of Japan, Taiwan and Singapore, which played similar roles (Amsden 1989; Deyo 1987; Johnson 1982; Woo 1991; Yeung and Olds 1998).

Recent studies have examined the discursive aspects of South Korea's developmental state. Because the authors of the developmental state referred to in the previous paragraph tended to work within the tradition of Weberian state theory, they focused their analyses on government bureaucracy and the political elites who controlled it. As such, discursive aspects of the developmental state have not been illuminated enough. Cho Hee-Yeon (2000), a sociologist, figures prominently in discussions of the discursive aspects of the developmental state. He argued that anticommunism was the fundamental idea that determined the developmental regime. Park Jung Hee invoked anticommunist sentiment when he emphasised that industrialisation and economic development were tools in the war against communists. Workers and other South Koreans internalised this sentiment as a self-censoring mechanism. Self-censorship prevented resistance to 
the authoritarian regime. Anticommunism was effective discourse for most people because they had experienced the Korean War (1950-1953) and they remained fearful of potential future attacks from communist North Korea. Park Jung Hee claimed that the only road to peace was through the economic defeat of North Korea. Chang (2009) and Koo (1993) both note that anticommunist sentiment was used to suppress the advancement of workers' rights. Those who attempted to organise workers were brutally punished.

Nationalism served as another discourse used to support the state's moral legitimacy. As Woo $(1991,98)$ indicates, in order for a regime to legitimise itself successfully through industrialisation, it has to connect industrialisation with collective sentiment. Nationalism became the powerful collective sentiment for people who vividly remembered the brutality of Japanese colonialism during the 1940s. Park Jung Hee argued that "true" independence, meaning ultimate victory over the former coloniser, could only be achieved through economic growth (Park 1995, 14-15; Kim 2006, 69).

The hegemonic discourses of anticommunism and nationalism enabled South Korea to unite its diverse social groups under the agenda of industrialisation. As in Jessop's $(2007,208)$ theorisation of hegemony, these hegemonic discourses in South Korea helped legitimise both formal and informal sanctions against any individual who acted against this agenda.

These authors' examination of the hegemony and other discursive aspects of South Korean development helped us to understand that implementation of its economic policies was enabled not only by tight control of the bureaucracy but also through the discourse that it imposed on its workers. Nevertheless, there are two reasons to go beyond the existing literature.

First, hegemonic discourse does not dictate how people should act in everyday work and life situations. Hegemonic discourse must be simple enough to be widely applicable. However, the simplistic nature of discourse prevents it from being concrete enough for application to diverse everyday situations. This is especially problematic, for South Korea and other cases, because industrialisation requires a transformation of society as a whole that includes a shift from people's pre-industrial conduct to industrial conduct. When the state attempts to implement economic policies, if individuals are incapable or unwilling to behave in a compatible manner with those policies, those policies will not have the intended effect. For example, when the state wants to promote export, the state can lure businesses with tax or financial incentives. However, businesses must be able to rely on their workers. When the transport of products over long distances requires a tighter control of production schedules, businesses must be able to exert considerable control over the amount of work completed within a given time frame. Unless workers come to work in a timely fashion, are disciplined enough to continue work until given breaks and are willing to work overtime, long-term relationships with foreign traders will not be possible. In order for workers and other citizens to act in accordance with hegemonic discourse, they must first agree with it. However, agreement alone is not enough; behaviour often contradicts beliefs. Even if citizens agree with the hegemonic discourse, translation of that discourse into action requires further efforts. Therefore, the hegemonic discourse must be reproduced and translated each time in every daily situation it enters. Thus, instilling hegemonic discourse in workers' minds and bodies is critical. Nevertheless, this issue has not received sufficient exploration in the previously cited literature on the hegemonic discourse of the developmental state, nor has it been properly explored in the wider literature on hegemonic discourse (Barnett 2005). Furthermore, in the case of South Korea, the state acted as the agent of fundamental and rapid social transformation of the entire society and economy. The task of transforming citizens' conduct and instilling an acceptance of the hegemonic discourse was formidable. Hence, by illuminating the way in which the state instilled hegemonic discourse into people's everyday lives, this article aims to provide a fuller picture of the developmental state.

Second, the nondiscursive elements of hegemonic discourse have not received sufficient examination. In addition to the development of the discourse itself, social and political institutions must be developed that will continuously reproduce, circulate and internalise the discourse. 
Therefore, it is critical that we examine hegemonic discourse along with the development of the institutions that contribute to the discursive process.

To resolve these two problems, we propose the concept of "developmentalist governmentality", based on Foucault's discussion of "governmentality" and "apparatus" (dispositive) and on the reinterpretations of those concepts provided by other scholars.

First, we use governmentality to resolve the first of the two problems of the literature. Foucault argued that governmentality "conduct[s] individuals throughout their lives by placing them under the authority of a guide responsible for what they do and for what happens to them" (Foucault 1997, 68). In this process, "the work of government is reconfigured as training, fostering, inciting and if needs be, coercing individuals to adopt self-regulating behaviors and to govern themselves as if they were free" (Huxley 2008, 1640). We can use this definition of governmentality to solve the first problem of the hegemonic approach to South Korean development mentioned earlier. This definition emphasises the pervasiveness of power and the dispersed practice of governing. Thus, if we combine this definition with Foucault's other works that emphasise the omnipresence of power, we can better understand that the discursive process of the developmental state was concerned with both producing and reproducing hegemonic discourse among its workers.

To explain the next concept, apparatus and its contribution to this research, we must clarify its relationship to governmentality. Foucault did not - at least explicitly - explain this relationship. In fact, Foucault, among others, offers various definitions of these two concepts that tend to overlap. In one instance, Foucault's defines governmentality as "an ensemble formed by the institutions, procedures, analyses, and reflections, the calculations and tactics that allow the exercise of this very specific albeit complex form of power" (Foucault 1998, 8). Note that this definition is not altogether different from his definition of apparatus:

a thoroughly heterogeneous ensemble consisting of discourses, institutions, architectural forms, regulatory decisions, laws, administrative measures, scientific statements, philosophical, moral and philanthropic propositions ... The apparatus itself is the system of relations that can be established between these elements. (Foucault 1972, 174)

To clarify the relationship between these two concepts, we applied one of Colin Gordon's (1991) definitions of governmentality: governmental rationality. Gordon proposed that a governmental rationality is "a way or system of thinking about the nature of the practice of government ... capable of making some form of that activity thinkable and practicable both to its practitioners and to those upon whom it was practiced" (Gordon 1991, 3). By defining governmentality as governmental rationality, we can then clarify that governmentality is mainly the abstract principles of production, circulation and reproduction of dominant discourse.

On the other hand, we define the apparatus as a more concrete mechanism through which governmentality materialises. As defined by Foucault in the quotation above, an apparatus is a heterogeneous ensemble of the discursive and nondiscursive. This recognition of heterogeneity permits us to consider the institutional arrangement through which the dominant discourse passed. Thus, it enables us to resolve the second problem of the hegemonic discourse literature that we previously discussed.

Based on these two concepts, the formation of the developmental state can be seen as the formation of a particular governmentality that includes, but is not limited to, a particular political system. Although it is beyond the scope of this article to explain the totality of developmentalist governmentality, we can claim that developmentalist governmentality transforms its subjects into a subordinate working class through a combination of "technologies". These may include the use of harsh disciplinary mechanisms, the application of military organisation to ordinary citizens, 
and the use of ideological persuasion as a means to spread anticommunism and nationalism. As the first step in the development of our theory of developmentalist governmentality, we analysed the Saemaul movement, which was an important apparatus of South Korea's developmentalist governmentality. Of the various technologies used within the movement, we chose to study the Saemaul leaders as the state's organisational technology.

\section{The discourse and organisation of the Saemaul movement}

In 1970, the Saemaul movement (hereafter, the movement) began as a rural community development initiative in South Korea. Both official and unofficial records suggest that President Park Jung Hee personally initiated it (Ministry of Home Affairs 1980, 1). The movement, whose original aims were economic development and the cultural modernisation of rural areas, continues to this day. ${ }^{2}$ However, the movement became significantly less vibrant following the assassination of Park in 1979. In this article, our analysis is limited to the time before the death of Park.

Official state publications report that the movement implemented such diverse rural economic development measures as the enhancement of the productivity of rice farming and the organisation of producers' associations. These publications also claim that the movement made significant contributions to income growth in rural areas (see, for example, Ministry of Home Affairs 1980). However, as Lee (1984) has illustrated, most of those measures were launched prior to 1972; they were simply relabeled after the movement began. Furthermore, income levels in rural areas grew at a much slower rate than the national average. Therefore, it is relatively safe to conclude that the movement's direct effects on income level growth in rural areas were limited.

For almost a decade, the movement operated on a huge scale with a strong commitment from the state. Although the movement exerted limited effect on income level growth, the government's continued support suggests that the movement was a part of a bigger plan. We can view the movement as an apparatus that diffused developmentalist governmentality to rural communities, the governmentality that had already been established in major industrialised cities such as Seoul.

In fact, President Park openly stated that he believed mental development to be more important than economic development: "I attach a larger importance to villagers' mental development than economic development" (Presidential Secretariat 1973, 18).

Park also emphasised the connection between economic development and non-economic changes. He argued that economic development and mental development are two sides of the same coin (Presidential Secretariat 1973, 18). He stated that mental development was an important prerequisite for economic development: "the spirit of self-help and attitude to take initiatives are the fundamental elements in making our villages prosperous" (Presidential Secretariat 1973, 847).

The movement placed great importance on non-economic change. Therefore, it is likely that the movement's early focus was on projects that had a demonstrative effect but not necessarily economic value. As its first project of the movement, the state distributed cement and iron rods to 34,000 rural villages. The villagers used these construction materials in community infrastructure projects such as the building of community centers and the expansion of main streets. The villagers donated their own money and labour to complete these public projects. The scale of the movement grew quickly. In 1971, government aid amounted to 35 million USD. This amount grew to 1.8 billion USD in 1978 , which was a 5,100 per cent growth (Ministry of Home Affairs 1980, 182). For the state, these accomplishments were economically efficient because labour costs were almost nil thanks to the "voluntary" labour of the villagers (Oh 2003, 473).

The word Saemaul literally means "new village". The name implies that the movement would transform villages from old to new. The Three Saemaul Spirits - diligence, self-help and cooperation - epitomise the movement's cultural values. The cultivation of these ideals was 
widely propagated as a kind of "mental revolution". At a more practical level, the mental revolution included abstinence from gambling and moderation in alcohol use; renovation of houses, adoption of work clothes as everyday attire, minimisation and simplification of traditional rituals and ceremonies; practice of family planning; and avoidance of the practice of superstitions such as goot (shamanistic prayer ritual) and dongjae (collective prayer for the village's guardian deity).

It is important to note that the movement sought to discourage cultural values that were not compatible with capitalist working class ethics. The Three Saemaul Spirits represent the ideal attitude of a capitalist worker. Because spiritual elements of traditional culture, such as goot and dongjae, were not useful to a capitalist economy, they were labeled as superstitions. The movement could not directly criticise the legitimacy of some rituals (for example, jaesa, a family ceremony for deceased ancestors) due to their extreme importance within South Korean culture. It did, however, criticise the logistic aspects of those rituals, such as their high frequency and consumption of large amounts of food. In addition, habits considered undesirable for an ideal capitalist labourer, such as gambling and drinking, were ethically sanctioned.

To instill new values, the movement's discourse attached a variety of negative meanings to "old" ways of thinking. Park argued that, in the past, peasants wasted time "not working, drinking in the daytime, and gambling in the daytime". He offered the generalisation that "for centuries, Koreans were never enterprising, often in mannerism and defeatism" (Presidential Secretariat 1973, 912). He concluded that Korea remained a small country because of its adherence to old attitudes. He claimed: “our ancestors couldn't even occupy Sujima Island, ${ }^{3}$ which is right in front of us" (Presidential Secretariat 1973, 913). If we consider the fact that diverse rural development initiatives sprang up among ordinary peasants in the 1960s (Kim 2009), then Park's attacks on "old" villages appear, at best, to be grossly exaggerated.

In terms of organisation, the state directly controlled the movement from the top. From its inception, the movement's accomplishments were presented to the President in the Monthly Presidential Meeting for Economic Review. In 1972, the National Committee for the Saemaul movement was launched, and its membership consisted of deputy ministers from several relevant departments of the central government. Provincial, county, town and village committees were formed below the National Committee. Thus, all levels of government were connected vertically (Ministry of Home Affairs 1980, 154-170). The highest level of government, often President Park himself, passed agendas down to village committees. Although the movement was led by the state, villagers' participation was not forced. Widespread discontent, fueled by feelings of rural backwardness, existed among the peasantry. Hence, the movement easily gained support among them (Koh 2006). Therefore, in agreement with Kim (2009), we consider the movement to be a successful mobilisation and institutionalisation of ordinary peasants' existing desires and "bottom-up actions", rather than a creation of new desires and actions. The movement mobilised diverse groups that traditionally experienced oppression in rural villages. In particular, these groups included young people who were oppressed by formal and informal seniority systems; women who were victims of gender discrimination; and peasants who were still treated like Sangnom (members of lower caste) under the feudal caste system, which had been legally abolished decades before but continued to function due to the landlord/peasant division (Yoo 2001). In the movement, these oppressed groups found a state-supported opportunity to improve their situation. However, without the Saemaul leaders, the movement could not have gained wide support. We will explore this fact in the two sections that follow.

\section{Saemaul leaders as the organisational technology}

The state instructed residents of each village to elect a man and a woman to the positions of Saemaul leader and women's leader, respectively. ${ }^{4}$ The state did not regard these elections as 
official functions because they occurred during informal village gatherings. The state would later approve the villagers' election choices by providing elected leaders with ID cards, called Saemaul leaders' cards. Leaders received these cards after successful completion of the Saemaul Leader Training Programme. ${ }^{5}$

Various Korean researchers have concluded that, from the state's perspective, a Saemaul leader understood government policies and administered them. A Saemaul leader was also expected to understand President Park's ideas for the movement, to educate villagers (Hwang 1980, 134-42) and to control formal and informal voluntary associations within the village (Choi 1977, 317, 326). At the same time, a Saemaul leader represented his village on a national level and publicised his village's success stories nationwide (Kim 1999, 64).

Although Saemaul leaders did not receive a formal salary from the state, they did receive economic rewards for their service. They had priority access to government-assured agricultural loans, available at an interest rate for only a fraction of the market rate; train or ferry tickets, which were difficult to book during holiday seasons; scholarships for their children; telephone installations, which normally required long waiting periods or bribery; and employment as government bureaucrats. On occasion, they were allowed to be the sole vendor of all "goods from the city", which ranged from processed food to household products such as soap and toothpaste (Lee 1981, 261; Choi 1978, 95). Furthermore, local government offices were required to treat Saemaul leaders in a manner equal to local state agency heads (Kim 1999, 64).

Saemaul leaders also received nonmaterial rewards. Invitations to nationwide conferences of Saemaul leaders were regarded as huge honours. Successful leaders received awards and medals (Kim 1999, 64). President Park's personal interventions were another example of a nonmaterial reward. He frequently invited Saemaul leaders to the president's office to share their thoughts with ministers and other high ranking bureaucrats. Villagers thought of such treatment as equivalent to knighting or similar royal validation. That is because it had only been several decades since the monarchy dissolved and also because Park Jung Hee was a king-like dictator. ${ }^{6}$

Villagers seemed to acknowledge that it was advantageous for Saemaul leaders to be affiliated with the state. That way, they hoped, their Saemaul leader would have better access to useful information from outside the village (Choi 1978, 99).

In addition to being civilians and bureaucrats simultaneously, Saemaul leaders were members of their villages and yet, at the same time, outsiders. First, we will examine the aspect of the outsider. As Choi (2003) stated, the Saemaul leaders participated in the modern bureaucracy and the modern educational system. The Ministry of Home Affairs estimated that 84 per cent of Saemaul leaders were between the ages of 30 and 40 . Only 7 per cent of the leaders were over 50 years old (Ministry of Home Affairs 1980, 27). These figures imply that the majority of Saemaul leaders belonged to the generation that had modern education as well as military experience.

Under the Japanese colonial government, modern education was available to only a small portion of the population. The generation that grew up in the 1950s and 1960s was the first group to receive at least primary education from modern institutions. Many in this group received secondary education as well. Some even earned bachelor's degrees from universities in Seoul. A large percentage of their parents' generation was educated in the Confucian tradition or not formally educated at all. Hence, this new generation considered themselves better informed about the changing world outside their villages.

Compulsory military service also gave this new generation of young men exposure to modern technology and modern organisational principles. It has been widely noted that, in the $1950 \mathrm{~s}$, the military was one of the most advanced sectors of South Korean society. Although the rest of the country was run by institutions created three decades earlier by the colonial Japanese government, the military imported cutting edge technologies and organisational principles from the US Army. Because of South Korea's geopolitical importance, the US Army provided support to the South 
Korean Army. Furthermore, after General Park's military coup, former military officers began to occupy high positions within state bureaucracy. This added prestige status to the military. Goondaesik (or the military way of doing things) was considered both more efficient and more prestigious. Therefore, upon completion of their military service, the new generation of village men aspired to maintain military discipline and to apply it in their villages. As Kim $(2009,160)$ writes, many young men attempted to form daily exercise groups, to organise things in their "right" places and to adhere strictly to a preset daily timetable, etc.

In addition, Saemaul leaders were familiar with the capitalist market system. Unlike the older generation's leaders, who lived their lives under virtually autarkist village economies, Saemaul leaders lived in Seoul or other major cities that underwent rapid industrialisation during the 1960s and 1970s. Therefore, Saemaul leaders were more knowledgeable regarding commercial agriculture. Saemaul leaders were often successful commercial farmers prior to their service as Saemaul leaders. Consider the case of Chon Yong Woo, shown below:

I was born in Seoul, finished college and became a high school teacher ... [after moving to a village] I organised an agricultural association to contribute to increasing fellow villagers' income ... In one year, we produced 240 tons of spring onion ... Traders from Seoul saw this tremendous amount of spring onion and argued that they could pay only $300 \mathrm{KW}$ per a box. Fellow villagers were devastated. I solemnly told the villagers that $300 \mathrm{KW}$ is less than the price of seed, so we should use our entire harvest as seed for the next year. All of the villagers agreed. This put traders in a desperate situation ... Facing our unity, the traders eventually paid what we demanded, after three weeks. Then, I made a special contract with four wholesale traders in Seoul. Under that contract, I was informed of the early morning auction price of spring onion each morning, and sold spring onion for a good price. I also made a contract with a trucking company under which the truckers had to transport whatever quantity we demanded. That way, we could send the amount that traders needed on time. (Chon 1976, 278)

In our examination of memoirs and speeches, we found many similar reports by Saemaul leaders. Villagers seemed to have acknowledged the superior knowledge of Saemaul leaders. According to Kim, villagers wanted Saemaul leaders to have agricultural knowledge that the villagers themselves did not possess (Kim 1999, 67).

Armed with modern education and military experience, the new generation of villagers grew increasingly critical of the cultural traditions of their villages. Twenty-five years after the end of Japanese colonialism and less than 20 years after the end of the Korean War, most villages continued to suffer from extreme poverty. The state of these impoverished villages stood in stark contrast to the state of industrialising cities that already showed the signs of an economic boom. The new generation were not aware that gaps between cities and villages were common in the early phase of economic growth in most countries. In addition, they failed to understand that the state's emphasis on export industries only served to widen these gaps. Instead, they were persuaded that villagers, unlike the working class people in cities, were lazy and ignorant due to the negative effects of Confucian education and traditional culture. Members of the new generation viewed anything old as a barrier to development. Members of the older generation, who remained loyal to old customs and traditions, were seen as reactionaries.

These differences, however, did not make Saemaul leaders into complete outsiders. Before their short stays in cities, they resided for long periods in their villages. A small number of Saemaul leaders were born outside their villages. Prior to becoming Saemaul leaders, they resided in their villages for many years. Furthermore, Saemaul leaders were not alone in their distinctive positions. In general, there were, at the very least, several people of the leaders' generation in each village who possessed similar modern educational backgrounds and military experiences. This made future Saemaul leaders better suited to the village. ${ }^{7}$ 
Because of the aforementioned facts, the emergence of a new generation and the election of Saemaul leaders were not just a simple generational change. It was, rather, an influx of modern capitalist conduct. From a governing perspective, the emergence of the new generation meant that subjects would be more open to government by modern methods. The state could govern by the use of economic incentives and judicial and political means. By bestowing the title of Saemaul leader to younger members and, thus, empowering the young, the state could effectively accelerate the power shift between generations. Previously, it would have taken much longer for younger members to become part of the central power organisation within the villages.

\section{Four tactics for disseminating discourse through organisation}

Because of their dual roles, Saemaul leaders were able to act in ways that would have been difficult for state bureaucrats. While the local bureaucracy often legally or illegally forced villagers into projects, Saemaul leaders tended to use persuasion as a tactic to engage villagers. In the memoirs and speeches examined for this study, we identified four tactics employed by Saemaul leaders. In the following section, we will describe each tactic in detail. We will then discuss reasons why these tactics were effective when employed by Saemaul leaders but less effective when employed by purely civilian leaders or local civil servants.

\section{Dissemination of practical knowledge}

One of the most frequently used tactics of persuasion is demonstration. On many occasions, Saemaul leaders demonstrated ways to grow new crops or tend new farm animals that were more profitable than rice farming or other traditional types of agriculture.

I thought a meat cow would be a better money maker than herb farming ... I bought a meat cow, fed it for about 100 days, and sold it. I did this two to three times a year. By doing so, I could earn 300 to 400 thousand KW per year. For this, I earned the villagers' respect and could persuade other villagers to do the same. (Chong In-Sook 1979, 996)

Application of the tactic of demonstration was not limited to farming. In the area of household affairs, women's leaders primarily practiced demonstration: "I first persuaded four women who were sympathetic to me. The five of us bought materials, remodeled kitchens and showed the kitchens to the public. In the modern kitchen, we felt as if rice cooked itself' (Chong JongYoon 1979, 1008).

Another successful application of the tactic of demonstration in the household affairs area was the use of bookkeeping (Lim Kwang-Mook, quoted in Han 2006, 361). Demonstration became an effective method of dissemination through the sharing of practical knowledge and the presentation of successful results.

\section{Direct persuasion and peer pressure}

Direct persuasion, often accompanied by peer pressure, was another commonly used tactic. Village meetings offered many opportunities to apply this tactic because peer pressure was easier to employ when a majority of villagers was present.

We decided that we should rebuild the bank of the stream that overflows almost every year ... On our first day of work, only 11 people came ... I called for a village meeting and ... appealed to them to come to the site, even if they did no work. "Why do you want to pass on your poverty and dirty work shirts to your children? We can be better off if we cooperate. This stream can take away your farm, 
house, or your lives at any moment." I begged and begged. After that, the number of volunteers increased. (Choi Byung-Geol quoted in Ministry of Home Affairs 1979, 998)

It is important to note that this tactic was applied in a more complicated situation than in those situations where demonstration proved sufficient. In the above excerpt, the scale of the job was large and the effects were obvious. Instead of focusing on the effect of a job, villagers tended to pay more attention to the possibility of large-scale collaboration within the community. A Saemaul leader had to demonstrate that he had the support of a majority of the villagers. He accomplished this by speaking publicly to the gathered villagers. In doing so, he combined persuasion with peer pressure.

\section{Sacrifice}

When necessary, Saemaul leaders exhibited self-sacrifice in order to inspire villagers. In particular, financial sacrifices seem to have been a consistent part of the job.

The planned expansion of the village's main street would require occupying almost 10,000 square meters of private land. Obviously, villagers were vigorously against the plan ... For the person who would lose 150 square meters, I gave 300 square meters of my farm, and for 330 square meters, I gave 660 square meters. (Chong Jong-Yoon, quoted in Ministry of Home Affairs 1979, 997)

All but a few of the Saemaul leaders' memoirs and speeches contain similar stories that describe sacrificial acts such as giving up one's own house, farm or other property. Sometimes, the financial sacrifices were so extreme that the leaders who made them fell into poverty: "In my first year of the job, I could not take care of my fruit farm. That winter, my family would not have survived the winter without donation from other villagers" (Han 1979, 1003). Another leader wrote: "I learned later that my wife had to sell the wedding ring to buy food" (Yoo 1979, 1015-1016).

On other occasions, the sacrifice went beyond money or assets:

A rice mill was built and villagers wanted to use it. But nobody volunteered to manage it ... I had to do it myself. One day, I put down my baby in the bedroom and was coming to the mill. The baby crawled out of the bedroom, fell to the ground, and got a bone fracture ... This story spread to all villagers and changed them. Now the mill is managed collectively. (Ministry of Home Affairs 1980, 900-901)

It is possible that these cases were extreme or exaggerated. However, the fact that these stories appear in official state publications shows that they were at least believable, which in turn demonstrates that sacrifice was a common persuasion tactic used by Saemaul leaders.

\section{Violent confrontation}

Sometimes, persuasion took a more violent form. A women's leader wrote the following:

People gossiped that I was not docile and charming enough for a newlywed woman. But I didn't care. I, along with a few other women, would break in [to] the gambling room and mess up the cards, screaming and yelling. This aggressive actions combined with other kinds of persuasion got rid of gambling and drinking much faster than in other villages. (Chong In-Sook, quoted in Ministry of Home Affairs 1979, 1007)

In several cases, women broke into gambling rooms and literally burned the cards when their husbands changed houses every night in an effort to avoid capture (Kim 1977, 51). 


\section{The advantages of Saemaul leaders' duality}

The four tactics described above demonstrate the advantages of the Saemaul leaders' role as agents of both the state and village society. In this section, we will explain how the dual nature of this role contributes to the performance of each of the four tactics.

Demonstrations do not always change the observers' behaviour. To follow a Saemaul leader's demonstration of such things as new crops, a new kitchen or new bookkeeping techniques, villagers had to change the way they worked or managed their lives. Thus, these changes posed serious commitments. Learning that a leader's experiment was successful was not enough to inspire commitment. Leaders had to persuade villagers that the experiments would succeed for them and that the benefit generated by the experiments would be large enough to recover the cost of giving up their old ways. In order to achieve these large-scale changes, two different kinds of trust were required. First, villagers had to believe that the leader had better judgment about new information. Second, villagers had to believe that the leader was trustworthy. The first kind of trust could be more easily achieved by a state bureaucrat, because villagers knew that state bureaucrats had gone through the modern educational system and had access to up-to-date information. The second kind of trust could be more easily achieved by a fellow villager because villagers knew each other personally and had multiple mutual relationships. Thus, they were less likely to deceive one another. The dual nature of the Saemaul leaders' role placed them in positions where they could draw upon each kind of trust.

With respect to this topic, we must highlight the role of women's leaders. In a village where traditional ways of life still persisted, the spheres of men and women did not perfectly overlap. Therefore, a woman had to perform a demonstration within the women's sphere. If a man performed a demonstration, the result would not have been much different from the result achieved by a local civil servant because both were outsiders of the sphere of village women's work and life.

Direct persuasion by peer pressure required an even more complicated procedure. The requirements for persuasion are similar to those for demonstration. Local civil servants had the power to threaten villagers. In fact, records indicate that, during the movement, civil servants imposed legal and illegal sanctions on villagers who did not cooperate. Reports show that local civil servants often forced villagers to renovate traditional houses or change crops. The punishments for disobeying these orders were harsh (for example, the demolition of the villager's house or expulsion from the village). However, these methods might have increased resentment in the long run and might have made the movement less sustainable. Although peer pressure may have caused resentment, it served as a better tactic for two reasons. First, villagers would have understood that a proposed rule had been agreed upon by the majority of their fellow villagers; they would have felt at least partially obliged to concur. Second, because the peer pressure originated in the group, no particular individual would be the focus of resentment. The role of women's leaders was important for persuasion by means of peer pressure: women could persuade other women, who could, in turn, pressure their husbands.

Sacrifice was more effective when performed by Saemaul leaders rather than by local civil servants. Saemaeul leaders were fellow villagers; the other villagers understood the meaning of their sacrifices. Additionally, because villagers were familiar with Saemaul leaders' economic and social conditions, they tended to be less suspicious of hidden agendas.

Whether its source was civil servants or Saemaul leaders, violent confrontation would seldom have had positive impacts over time. However, the consequences of violent confrontation would have been less severe for Saemaul leaders. The reasons for this are similar to those for peer pressure. These reasons are even more apparent in the case of women's leaders. The interventions in gambling houses by women's leaders mentioned earlier provide a helpful example. If a local 
civil servant had performed such an intervention, the gamblers would have either attempted to bribe the official or attempted to avoid him entirely by frequently changing their location. After a fruitless search or as a result of bribery, the civil servant would have fulfilled his duty by reporting that gambling did not exist in the village - a principal-agent problem. However, in the case of women's leaders, the principal-agent problem would not have existed because the women's leaders were women among fellow women who could have lost their family assets due to their husbands' gambling. In addition, the information problem would not have existed either because the wife of the house where the gambling took place could have served as an informant. The women's leader and her associates could have pressured any of the wives in the village to play this role.

\section{Theoretical implications}

During the 1970s, the Saemaul movement contributed to the dissemination of a unique conduct that served the policies geared toward the industrialisation of South Korea. We find that Saemaul leaders acted in the dual role of civilian and bureaucrat. First, they were elected by villagers. Then, their official organisations were created within and across villages. The developmental state offered both formal and informal support to the leaders and their organisations. Thus, Saemaul leaders were considered to be "half-civilian, half-bureaucrat" individuals. This duality of role facilitated the dissemination of capitalist working-class ethics and practical knowledge about the way capitalism works in rural villages where cultural norms lagged behind those of industrialised cities. For the state, Samaeul leaders were the conduit through which developmentalist governmentality circulated. Without the dual role played by Samaeul leaders, the state would have struggled to penetrate into the villagers' everyday work and life situations. Hence, we conclude that the assignment of a dual role to Saemaul leaders was an effective organisational technology Saemaul movement, which was an important apparatus of the developmental stage.

These findings contribute to understanding the importance of organisational technology in the transformation of subjects' conduct. For a new conduct to emerge, new discourse must be deployed. Conduct can often be related to values. Therefore, the process of abandoning old ways in favour of new ones is usually a difficult one. Often, complicated and painful steps must be taken before a new way of thinking is accepted by the general public. This tendency leads to the importance of early innovators and their organisations. Early innovators are those individuals who understand the new social structure and develop a new conduct before other individuals do so. These early innovators are often reluctant to act upon the new discourse because they are unsure about how those around them will react. Their reluctance places those individuals who retain traditional conduct in a more powerful position. When this occurs, external support for early innovators might encourage more rapid changes. The state may serve as the agent of that support; however, the state is not always able to understand and control the details of everyday lives. Propaganda spread through mass media and formal educational institutions may prove helpful; however, it cannot fully achieve the objectives of the state. The simplified version of the dominant discourse deliverable through mass media and formal educational institutions may not be directly applicable to every work and life situation. For this reason, an agent of the new conduct should be present in every situation. As such, in its attempt to change conduct by inserting itself into day-to-day life, the state may extend itself toward everyday life and work situation of its subjects.

This finding enables us to understand how the workings of organisation and discourse intertwine. The interaction between organisation and discourse has been an important topic of study in the fields of industrial engineering and organisational sociology. The well-known Hawthorn Factory experiment (Mayo 1949) showed that discourse within informal organisations has a 
strong impact on workers' behavior. The Quality Circle in Japan (Marks et al. 1986) attempted to facilitate changes in conduct throughout a change in organisation. It is unfortunate that the fields of state theory and development studies have paid limited attention to this issue. In an attempt to fill some of this gap, this article shows that a half-civilian and half-bureaucratic organisation can be an effective medium for the dissemination of a dominant discourse to various segments of a society. An organisation is much easier to control than the discourse itself because the members of the organisation can be controlled by political power and financial incentives. It is also easier to design an organisation that specifically targets a certain segment of the population. We learn in this case study that the Saemaul leaders were an organisational technology that specifically targeted rural areas. From this, we learn that organisational technology is one of the most critical of the various technologies that make up an apparatus.

Through appreciation of the importance of organisational technology, we can reasonably suspect that recent discussions about the everydayness of the state in geography, anthropology and development studies falsely separate everydayness from other state functions. The current literature on this matter has found that big issues, such as war or economic policy, occupy only a small part of the state's work while the everyday maintenance of people's lives (such as street cleaning, building regulations, park management, parking control) occupy a large part (Ferguson and Gupta 2002; Painter 2006). However, in our research, we found that a well-designed organisational technology could permit dealing with some of the big national issues at an everyday level.

The Saemaul movement functioned as an integral part of a structural transformation, so one cannot say it was about the everyday maintenance of citizens' lives. However, structural transformation required the transformation of individual conduct, which, in turn, required the state's intervention into everyday life. The Saemaul leaders and their organisations helped the state contact villagers at the everyday level and deal with behavioral conditions for industrialisation there. From this example, we can conclude that the everydayness of the state existed in both matters of daily maintenance and matters of structural transformation.

In reference to the developmental state literature, our findings show that light should be shed on the micro mechanisms of the production and reproduction of subjects who actually carry out the imperatives of the developmental state at their everyday lives and work situations. Without a transformation of villagers' conduct, the inclusion of villagers and the rural economy in the economic development, which is based on a hyper-militant attitude toward production and export, would have been extremely difficult. Similar mechanisms should have worked through application of different apparatus and their organisational technologies in different parts of the society. Further research is required in order to clearly identify diverse apparatuses devised by the developmental state; and better understand the developmentalist governmentality behind the design and function of those apparatuses.

\section{Acknowledgement}

Dr Sonn extends thanks to the National Research Foundation of Korea for its financial support of this research (grant no. NRF-2010-330-B00265).

\section{Biographical notes}

Jung Won Sonn is a lecturer in the Bartlett School of Planning at University College London. His main research interests include the urban, rural and regional dimensions of economic development in East Asia. He has published in several journals including Urban Studies, Environment and Planning $A$ and Antipode. 
Dong-Wan Gimm is an NRFK (National Research Foundation of Korea) Fellow in the Bartlett School of Planning at University College London. He is a planning theorist and an urban historian specialising in the socio-spatial aspects of planning under the developmental state.

\section{Notes}

1. This classical concept is still often used in development studies. See, for example, Brinkman and Brinkman (2005) and Nkansah and Amankwaa (2001) among others.

2. Beginning in 2000, the Korean International Cooperation Agency used the movement as a model for international aid projects in parts of Asia and Africa.

3. Sujima Island is located in the Korean Strait that divides Korea and Japan. This island has, since the beginning of written history, usually been regarded as part of Japan.

4. As the title suggests, the women's leader is not equal to the Saemaul leader. The women's leader is responsible only for women's affairs.

5. We were unable to confirm the total number of Saemaul leaders. However, it is a common assumption that that all rural villages had them. In the 1970s, more than 34,000 rural villages existed.

6. In part because of state-offered incentives and in another part owing to leaders' sympathy toward the aims of the movement, Saemaul leaders were extremely enthusiastic. One leader stated: "I cannot say there is anything perfect about me. But I am willing to burn myself to be the torch for my village" (Son 1972: 129). Similar statements appear frequently in various leaders' speeches and memoirs.

7. Park (1974) found evidence that the new generation supported Saemaul leaders. In his survey of 92 Saemaul leaders, Park found that 41 per cent consulted young men and women in the village before they accepted the job of leader. Only 17 per cent consulted family members and 12 per cent consulted senior villagers.

\section{References}

Amsden, A. 1989. Asia's Next Giant. Oxford: Oxford University Press.

Barnett, C. 2005. "The Consolations of 'Neoliberalism." Geoforum 36 (1): 7-12.

Brinkman, R. L., and J.E. Brinkman. 2005. "Cultural Lag: A Relevant Framework for Social Justice." International Journal of Social Economics 32 (3): 228-248.

Chang, D.-O. 2009. Capitalist Development in Korea. London: Routledge.

Chang, H.-J. 1994. The Political Economy of Industrial Policy. London: Macmillan.

Cho, H.-Y. 2000. "The Structure of the South Korean Developmental Regime and its Transformation-Statist Mobilisation and Authoritarian Integration in the Anticommunist Regimentation." Inter-Asian Cultural Studies 1 (3): 408-428.

Choi, C.-H. 1977. Community Development. Seoul: Bakyung-sa.

Choi, J. 2003. Self-help in Saemaul Movement. Seoul: Seoul National University.

Choi, Y. 1978. "The Socio-scientific Approach to the Study of Rural Saemaul Movement." Rural Economy 1 (1): $28-34$.

Chon, Y. 1976. "Essay of a Saemaul Leader: A Tenacious Mole." Local Administration 25 (278): 89-95.

Chong, I.S. 1979. "New Village Construction for Us All." In Glorious Footsteps, Ministry of Home Affairs. Seoul: Ministry of Home Affairs.

Chong, J.Y. 1979. “A Woman Leader with College Education who Revolutionised the Village.” In Glorious Footsteps, Ministry of Home Affairs. Seoul: Ministry of Home Affairs.

Deyo, F. C., ed. 1987. The Political Economy of the New Asian Industrialism. Ithaca, NY: Cornell University Press.

Evans, P. 1995. Embedded Autonomy: States and Industrial Transformation. Princeton, NJ: Princeton University Press.

Ferguson, J., and A. Gupta. 2002. "Spatialising States: Toward an Ethnography of Neoliberal Governmentality." American Ethnologist 29 (4): 981-1002.

Foucault, M. 1972. "Confessions of the Flesh." In Power/Knowledge: Selected Interviews and Other Writings 1972-1977, edited by C. Gordon, 194-228. New York: Pantheon Books.

Foucault, M. 1997. Ethics: Subjectivity and Truth. New York: New Press.

Foucault, M. 1998. The History of Sexuality. London: Penguin. 
Gordon, C. 1991. "Governmental Rationality: An Introduction." In The Foucault Effect: Studies in Governmentality, edited by G. Burchell, C. Gordon and P. Miller, 1-52. Chicago: University of Chicago Press.

Han, D. 2006. "New People, New Community and the Rushing Modern Era." In Parkjeoghee Period and Korean Modern History, edited by S. Jeong, 357-378. Seoul: Sunin.

Han, K.J. 1979. "Rich Present, Rich Future." In Glorious Footsteps, Ministry of Home Affairs. Seoul: Ministry of Home Affairs.

Huxley, M. 2008. "Space and Government: Governmentality and Geography." Geography Compass 2 (5): $1635-1658$.

Hwang, I. 1980. Comprehensive Rural Development of Korea. Seoul: Korea Rural Economic Institute.

Jessop, B. 2007. State Power: A Strategic-Relational Approach. Cambridge: Malden Polity Press.

Johnson, C. 1982. MITI and the Japanese Miracle: The Growth of Industrial Policy, 1925-1975. Stanford, CA: Stanford University Press.

Kim, D. 1977. Small Rewarding Samaeul. Seoul: Daehangongronsa.

Kim, K. J. 2006. The Development of Modern South Korea. London: Routledge.

Kim, S. 1999. The Movement and the Embeddedness of State and Society in the 70s. Seoul: Yonsei University.

Kim, Y. 2009. Saemaul Movement of Them. Seoul: Purunyeoksa.

Koh, W. 2006. "Saemaeul Movement in the Era of Park Chung-Hee Regime and 'Making the Nation." Economy and Society 69: 178-201.

Koo, H. 1993. State and Society in Contemporary Korea. Ithaca, NY: Cornell University.

Lee, M. 1981. Theory and Reality of Saemaul Movement. Seoul: Saemaul Movement Research Institute, Seoul National University.

Lee, M. 1984. Manufacturing Industry Development and Korean Farming Village. Seoul: Seoul National University Press.

Marks, M., P. Mirvis, E. Hackett, and J. Grady. 1986. "Employee Participation in a Quality Circle Program: Impact on Quality of Work Life, Productivity, and Absenteeism." Journal of Applied Psychology 71 (1): $61-69$.

Mayo, E. 1949. Hawthorne and the Western Electric Company. London: Routledge.

Ministry of Home Affairs. 1979. Glorious Footsteps. Seoul: Ministry of Home Affairs.

Ministry of Home Affairs. 1980. 10 Years History of Saemaul Movement. Seoul: Ministry of Home Affairs.

Nkansah, P. T., and A. Amankwaa. 2001. "Adequacy, Accessibility, and Goodness of Data." Journal of African Business 2 (1): 95-107.

Ogburn, W. F. 1922. Social Change with Respect to Culture and Original Nature. New York: BW Huebsch.

Oh, Y. 2003. Historical Reviews of Rural Saemaul Movement in the 1970s. Seoul: Korean Rural Economic Institute.

Painter, J. 2006. "Prosaic Geographies of Stateness.” Political Geography 25 (7): 752-774.

Park, D. 1974. "Role, Election and Skill of the Saemaul (New Community) Leader." Korean Journal of Public Administration 12 (2): 2048-2082.

Park, J.-S. 1995. "New Managerial Strategy and the Changes of the Factory Regime in Korea: Focusing on the Big Companies of Manufacturing Sectors." Asian Perspective 19 (2): 271-301.

Presidential Secretariat, ed. 1973. President Park Jung Hee's Speeches. Seoul: Presidential Secretariat.

Son, S. T. 1972. "Lighting a Torch with the Hope for Enlightenment of the Village." Local Administration 21 (221): 124-129.

Woo, J.-E. 1991. Race to the Swift: State and Finance in Korean Industrialisation. New York: Columbia University Press.

Yeung, H., and K. Olds. 1998. "Singapore's Global Reach: Situating the City-State in the Global Economy." International Journal of Urban Sciences 2(1): 24-47.

Yoo, H.K. 1979. "Dreams Give the Village Energy." In Glorious Footsteps, Ministry of Home Affairs. Seoul: Ministry of Home Affairs.

Yoo, J. M. 2001. An Analysis on the Experience of Women who Participated in State-led Development. Seoul: Ewha Woman's University. 